\title{
Evaluation of Anemia in the Residents of Tambaklorok Exposed to Plumbum
}

\author{
Budi Santosa* \\ Universitas Muhammadiyah Semarang, Semarang, Central Java, Indonesia
}

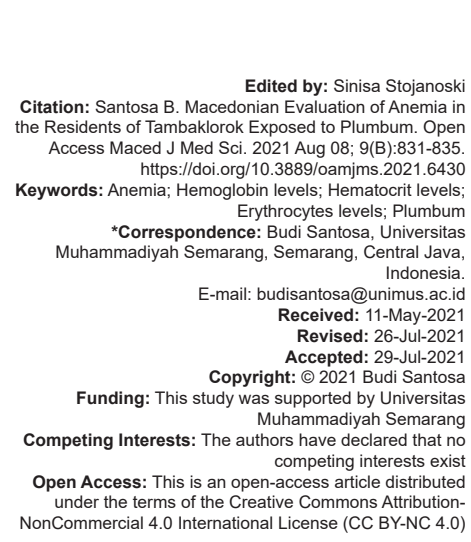

\section{Introduction}

Anemia is a health condition that involves reduced oxygen supply to body tissues [1] and it is a major problem in most developing countries. Globally, its prevalence was estimated to be $9 \%$ in developed and $43 \%$ in developing countries. Also, the condition is common among children and women in the childbearing age and according to a study, $47 \%$ of under-fives and $42 \%$ of pregnant women come up with it [2]. The target of the World Health Organization is to reduce anemia by $50 \%$ by 2025 [3]. Then, based on the results of the 2013 Basic Health Research (Riskesdas), the prevalence of anemia among women in childbearing age was $35.3 \%$ [4]. The condition could lead to maternal mortality, low birth weight in newborns, infection in the fetus and mother, premature birth, and miscarriage5. It could also lead to cognitive impairment, reduced levels of productivity, and susceptibility to infection, and even death [5]. Patients who are treated for more than a few hours and show the presence of pain [6].

Malnutrition and infection are the main causes of anemia, especially among children whose prevalence exceeds the national standard of $20 \%$ [7]. The presence of malignancies such as cancer and tumor, radiation, chronic diseases, drugs, toxic substances capable of damaging the kidney and liver, could also cause anemia, characterized by decreased hemoglobin $(\mathrm{Hb})$ levels and the number of red blood cells also known as erythrocytes [8]. An example of toxic substances causing anemia is plumbum $(\mathrm{Pb})$. Exposure to this substance causes the type of anemia known as microcytic hypochromic anemia. In this condition, there is a synthesis of heme, but the age of erythrocyte is usually short $<120$ days. The mechanism of $\mathrm{Pb}$ toxicity occurs due to the suppression of enzyme activity at the beginning, middle, and end of heme biosynthesis. The $\delta$ ALAD enzyme is the first to be inhibited by the presence of $\mathrm{Pb}$, which results in the cessation of $\delta \mathrm{ALA}$ from turning into porphobilinogen. This consequently increases the levels of $\delta$ ALA in the blood and urine. The intermediate enzyme inhibited by being exposed to $\mathrm{Pb}$ is coproporphyrinogen oxidase which leads to an increase in coproporphyrinogen levels. The ferrochelatase is the last enzyme inhibited by $\mathrm{Pb}$ and this leads to the increased levels of protoporphyrin in red blood cells/free erythrocyte protoporphirin, decreased heme and $\mathrm{Hb}$ levels, short life of red blood cells, and increased reticulocytes [9], [10].

Exposure to $\mathrm{Pb}$ is common in areas with fossil fuel combustion, industry, mining, production of battery, ammunition, solder, pipes, gasoline, paint, ceramic coating, children's toys, and contact of green 
shells and seaweed with water contaminated with $\mathrm{Pb}$, etc. [11], [12]. There are various industrial activities in Tambaklorok, located in the Northern part of Semarang, Indonesia, with a huge potential of polluting the environment. Schwartz et al. [12] reported that children living near primary lead smelters in the US of Idaho, had blood lead levels (BLLs) near $25 \mu \mathrm{g} / \mathrm{dl}$ and were associated with anemia in a dose-related manner. In addition, Drossos et al. [13] reported that children with $\mathrm{BLL}>30 \mu \mathrm{g} / \mathrm{dl}$ had a linear decline in $\mathrm{Hb}$ level. Whereas on the contrary, Froom et al. [14] suggested that $\mathrm{Hb}$ level did not correlate well with BLL and suggested that anemia is not related to lead at low BLL.

Based on research conducted [13], the waters in Tambaklorok contained about $0.06 \mathrm{ppm}$ of $\mathrm{Pb}$, but the maximum standard quality was set at $0.008 \mathrm{ppm}$ [14]. Furthermore, the research conducted [14], showed that the levels of $\mathrm{Pb}$ in the air around Tambaklorok were $8.41 \mu \mathrm{g} / \mathrm{m}^{3}$ more than the quality threshold value of $2 \mu \mathrm{g} / \mathrm{m}^{3}$ per $24 \mathrm{~h}$ and the highest compared with other areas in Semarang [15]. In addition, the level of pollution is increasing continuously due to the direct disposing of industrial wastes into the surrounding waters. This is a common phenomenon in the area because most of these industries are not equipped with waste water treatment plants IPAL, which makes the river and sea waters contain high levels of $\mathrm{Pb}$. Consequently, these $\mathrm{Pb}$ are accumulated in shellfish and other fish consumed by Tambaklorok residents. Prior to this period, there was no clear data of anemia condition among these residents being constantly exposed to $\mathrm{Pb}$. Therefore, the aim of this study was to determine the level of anemia among the residents of Tambaklorok, based on the characteristics of the respondents.

\section{Materials and Methods}

The cross-sectional research method was used with an analytic study approach testing the relationship of anemia based on the characteristics of respondents. It was conducted between January and March 2020. The study population was the residents of Tambaklorok divided into 5 hamlets, namely 12, 13, 14, 15, and 16 . The study samples were 104 residents selected based on the Lameshow formula [16].

This study uses a purposive sampling technique used to select respondents from 104 populations from the area without age group restrictions, consisting of children, adolescents, adults, the elderly, and people aged over 65 years who have lived in the area for at least 1 year. The age group includes adolescents (17-25 years), adults (26-45 years), the elderly (4665 years), and over 65 years. Then the picture of anemia was obtained from the measurement of $\mathrm{Hb}$, erythrocyte, and hematocrit $(\mathrm{Ht})$ levels using the impedance principle on the BZ 2600 hematology analyzer. Furthermore, the sample used was the venous blood without any special preparation such as fasting, limiting physical activity, etc. from the respondents. Questionnaires were used to collect data involving age, gender, length of stay, profession, personal protective equipment (PPE), smoking, consumption of shellfish, etc. A respondent is assumed to consume shellfish if taken at least once a week and smokers, if at least 1-5 sticks are taken per day. Then, the anemia condition was assessed based on the levels of $\mathrm{Hb}, \mathrm{Ht}$, and erythrocytes of the respondents described on a frequency distribution table. The data were subjected to the Gamma statistical test using the SPSS version 22 software. In addition, the parameters used for anemia include if the male $\mathrm{Hb}$ level was <13.5-17.5 and the female $<11.5-15.5 \mathrm{~g} / \mathrm{dl}$; male $\mathrm{Ht}$ levels $<40-52 \%$ and female $<36-48 \%$; then, the erythrocytes in male $<4.5-6.5$ million and female $<3.9-5.6$ million. Then, the mild, moderate, and severe anemia was determined based on an interval of $1 / 3$ below the lowest values for $\mathrm{Hb}, \mathrm{Ht}$, and erythrocyte counts

The ethical clearance for this research was granted by the Ethical Commission of the Medicine Faculty, UNISULA Semarang with the reference No. 064/III/2020/Commission/Bioethics. Then, the Head of Clinical Pathology Laboratory, Muhammadiyah University of Semarang, consented to conduct the research after receiving the ethical clearance results.

\section{Results}

Tambaklorok is located in the Northern part of the city of Semarang in Indonesia. It is a coastal area populated with fishermen, traders, factory workers, and few other professions. The entire population of the city is divided into five hamlets, namely, $12,13,14,15$, and 16. The respondents were 104 in number consisting of 26 men and 48 women, with 1 person in teenagers' group (17-25 years), 29 adults (26-45 years), 63 elderly people (46-65 years), and 7 people above 65 years old. Mild anemia was common among the women and elderly and in overall, there were $41 \%$ of the population with mild anemia with $\mathrm{Hb}$ levels $\pm 10.9 \mathrm{~g} / \%$. The overview of the condition based on gender and age is shown in Table 1.

Table 1: Anemia distribution by gender and age

\begin{tabular}{llllll}
\hline Gender and age & \multicolumn{2}{l}{ Result } & & Total \\
\cline { 2 - 5 } & Anemia & $\%$ & No anemia & $\%$ & \\
\hline Gender & 6 & 5.77 & 28 & 26.92 & 34 \\
$\quad$ Male & 37 & 35.57 & 33 & 31.7 & 70 \\
$\quad$ Women & & & & & \\
Age & 3 & 2.8 & 0 & 0 & 3 \\
$\quad$ Teenagers (17-25 years old) & 5 & 4.8 & 24 & 4.8 & 29 \\
$\quad$ Adult (26-45 years old) & 29 & 27.88 & 34 & 32.69 & 63 \\
$\quad$ Elderly (46-65 years old) & 6 & 5.76 & 3 & 2.8 & 9 \\
$\quad$ Old (>65 years old) & & & & & \\
\hline
\end{tabular}


The description of anemia based respondents' characteristics is detailed in Table 2 .

Table 2: $\mathrm{Hb}, \mathrm{Ht}$, and erythrocyte levels based on respondent characteristics

\begin{tabular}{|c|c|c|c|c|c|c|c|c|c|c|c|c|c|}
\hline \multirow[t]{3}{*}{ Characteristics } & \multirow[t]{3}{*}{$\Sigma$} & \multicolumn{12}{|c|}{ Results } \\
\hline & & \multicolumn{4}{|c|}{$\mathrm{Hb}$ levels } & \multicolumn{4}{|c|}{$\mathrm{Ht}$ levels } & \multicolumn{4}{|c|}{$A E^{*}$} \\
\hline & & $<\mathrm{n}$ & $\%$ & $\mathrm{n}$ & $\%$ & $<\mathrm{n}$ & $\%$ & $\mathrm{n}$ & $\%$ & $<\mathrm{n}$ & $\%$ & $\mathrm{n}$ & $\%$ \\
\hline \multicolumn{14}{|l|}{ Length of stay } \\
\hline $0-10$ years & 3 & 1 & 33.3 & 2 & 66.7 & 1 & 33.3 & 2 & 66.7 & 0 & 0.0 & 3 & 100.0 \\
\hline $11-20$ years & 9 & 5 & 55.6 & 4 & 44.4 & 4 & 55.6 & 5 & 55.6 & 1 & 11.1 & 8 & 88.9 \\
\hline $21-30$ years & 9 & 3 & 33.3 & 6 & 66.7 & 2 & 22.2 & 7 & 77.8 & 0 & 0.0 & 9 & 100.0 \\
\hline $\begin{array}{l}\text { Over } 30 \\
\text { years }\end{array}$ & 83 & 32 & 38.6 & 51 & 61.4 & 25 & 30.1 & 58 & 69.9 & 7 & 8.4 & 76 & 91.6 \\
\hline \multicolumn{14}{|l|}{ Profession } \\
\hline Fisherman & 24 & 5 & 20.8 & 19 & 79.2 & 5 & 20.8 & 19 & 79.2 & 3 & 12.5 & 21 & 87.5 \\
\hline Traders & 13 & 7 & 53.8 & 6 & 46.2 & 5 & 38.5 & 8 & 61.5 & 1 & 7.7 & 12 & 92.3 \\
\hline $\begin{array}{l}\text { Factory } \\
\text { workers }\end{array}$ & 1 & 1 & 100.0 & 0 & 0.0 & 1 & 100.0 & 0 & 0.0 & 1 & 100.0 & 0 & 0.0 \\
\hline $\begin{array}{l}\text { Fish } \\
\text { Farmers }\end{array}$ & 66 & 28 & 42.4 & 38 & 57.6 & 21 & 31.8 & 45 & 68.2 & 3 & 4.5 & 63 & 95.5 \\
\hline \multicolumn{14}{|l|}{ PPE } \\
\hline Do not use & 86 & 39 & 45.3 & 47 & 54.7 & 30 & 34.9 & 56 & 65.1 & 6 & 7.0 & 80 & 93.0 \\
\hline Incomplete & 13 & 2 & 15.4 & 11 & 84.6 & 2 & 15.4 & 11 & 84.6 & 2 & 15.4 & 11 & 84.6 \\
\hline Complete & 5 & 0 & 0.0 & 5 & 100.0 & 0 & 0.0 & 5 & 100.0 & 0 & 0.0 & 5 & 100.0 \\
\hline \multicolumn{14}{|l|}{ Smoker } \\
\hline Yes & 15 & 4 & 26.7 & 11 & 73.3 & 4 & 26.7 & 11 & 73.3 & 2 & 13.3 & 13 & 86.7 \\
\hline No & 89 & 37 & 41.6 & 52 & 58.4 & 28 & 31.5 & 61 & 68.5 & 6 & 6.7 & 83 & 93.3 \\
\hline \multicolumn{14}{|l|}{$\begin{array}{l}\text { Frequent } \\
\text { consumption } \\
\text { of shellfish }\end{array}$} \\
\hline Yes & 62 & 24 & 38.7 & 38 & 61.3 & 17 & 27.4 & 45 & 72.6 & 4 & 6.5 & 58 & 93.5 \\
\hline No & 42 & 17 & 40.5 & 25 & 59.5 & 15 & 35.7 & 27 & 63.3 & 4 & 9.5 & 38 & 90.5 \\
\hline
\end{tabular}

Considering Table 2, the levels of $\mathrm{Hb}, \mathrm{Ht}$, and erythrocytes less than normal were $\mathrm{Hb}(41 \%)$, $\mathrm{Ht}(32 \%)$, and erythrocyte counts $(8 \%)$, respectively. The levels of $\mathrm{Hb}$, less than normal were common among respondents not using PPE, amounting to 39 respondents (45.3\%). Low levels of $\mathrm{Ht}$ and erythrocytes were also observed in this group. The results of the statistical test showing the relationship between $\mathrm{Hb}, \mathrm{Ht}$, and the number of erythrocytes of the respondents are presented in Table 3.

Table 3: Result of statistical test of respondent's blood level

\begin{tabular}{|c|c|c|c|}
\hline \multicolumn{2}{|l|}{ Bivariate Test } & \multicolumn{2}{|l|}{ Result } \\
\hline Respondent Characteristics & $\mathrm{Hb}, \mathrm{Ht}, \mathrm{AE}$ & Number of Respondents & $p$-value \\
\hline \multirow[t]{3}{*}{ Length of stay } & $\mathrm{Hb}$ & 104 & 0.683 \\
\hline & $\mathrm{Ht}$ & 104 & 0.717 \\
\hline & $\mathrm{AE}$ & 104 & 0.569 \\
\hline \multirow[t]{3}{*}{ Profession } & $\mathrm{Hb}$ & 104 & 0.173 \\
\hline & $\mathrm{Ht}$ & 104 & 0.507 \\
\hline & $\mathrm{AE}$ & 104 & 0.196 \\
\hline \multirow[t]{3}{*}{ PPE } & $\mathrm{Hb}$ & 104 & 0.001 \\
\hline & $\mathrm{Ht}$ & 104 & 0.012 \\
\hline & $\mathrm{AE}$ & 104 & 0.645 \\
\hline \multirow[t]{3}{*}{ Smoker } & $\mathrm{Hb}$ & 104 & 0.246 \\
\hline & $\mathrm{Ht}$ & 104 & 0.701 \\
\hline & $\mathrm{AE}$ & 104 & 0.477 \\
\hline \multirow[t]{3}{*}{ Consume shellfish } & $\mathrm{Hb}$ & 104 & 0.857 \\
\hline & $\mathrm{Ht}$ & 104 & 0.373 \\
\hline & $\mathrm{AE}$ & 104 & 0.577 \\
\hline
\end{tabular}

$\mathrm{AE}$ : Anthal eritrosit.

Based on Table 3, the relationship between the use of PPE with the levels of $\mathrm{Hb}, \mathrm{Ht}$, and $\mathrm{AE}$ resulted in a $p$-value of 0.001 and 0.012 , respectively, which were $<0.05$. This is an indication of a significant relationship between the use of PPE with $\mathrm{Hb}, \mathrm{Ht}$, and $\mathrm{AE}$. However, the statistical tests involving other factors such as length of stay, profession, smoker, and consumption of shellfish resulted in p-value above 0.05 , meaning there was no significant relationship between these factors and the levels of $\mathrm{Hb}$, and $\mathrm{Ht}$, and $\mathrm{AE}$.

\section{Discussion}

The majority of the respondents profession, 83, had a length of stay longer than 30 years, with $38.6 \%$ having $\mathrm{Hb}, 30.1 \% \mathrm{Ht}$, and $8.4 \% \mathrm{AE}$ lower than normal. Comparing the length of stay in the exposed area with a length of work, these results are in line with a previous research which stated that there was a relationship between length of work and exposure to $\mathrm{Pb}$. According to Rustanti and Mahawati (2011), there was a positive correlation between length of work and exposure to $\mathrm{Pb}$ among fish farmers in Tambaklorok [17]. Normally, exposure to $\mathrm{Pb}$ is chronic, meaning it enters the body for a long time, even for many years, while accumulating in the blood. Its toxicity is highly dependent on this chronic exposure thereby leading to health effects such as anemia.

The respondents were mainly fishermen, traders, factory workers, though with other odd jobs. However, about $42.4 \%$, from respondents from fish farmers profession had $\mathrm{Hb}$ levels less than normal (anemia). Only one factory worker was found with anemia, while $53.8 \%$ of traders and $20.8 \%$ of fishermen were found with low levels of $\mathrm{Hb}$. However, the percentage of $\mathrm{Ht}$ and $\mathrm{AE}$ counts was slightly lower compared with $\mathrm{Hb}$. This could be due to $\mathrm{Pb}$ exposure for the first time would have an impact on the synthesis of heme, thereby reducing the $\mathrm{Hb}$ levels. Also, under certain conditions, $\mathrm{Pb}$ decomposes in the air, reacts with oxygen to form $\mathrm{Pb}$ oxide at a certain temperature, and inhaled in form of small particles usually $<5$ microns, thereby resulting to its toxicity through inhalation [18] This is likely to happen to people in areas with high exposure, such as the fishermen, traders, factory workers, and other professions. This could be the reason this research accounted for about $41 \%$ of respondents with mild anemia.

According to the results, most of the respondents did not use the PPE. This could impact on the majority having $\mathrm{Hb}, \mathrm{Ht}$, and $\mathrm{AE}$ levels less than normal. Based on laboratory results, respondents using the PPE in their place of work did not experience anemia in the form of normal $\mathrm{Hb}, \mathrm{Ht}$, and erythrocyte counts. Therefore, there is a significant relationship between the use of PPE with the levels of $\mathrm{Hb}$ and $\mathrm{Ht}$. The results are in line with a previous research which stated that the incomplete or non-use of PPE resulted in higher levels of $\mathrm{Pb}$ among workers compared with those using it. However, the use of PPE could only minimize the exposure to $\mathrm{Pb}$ but does not guarantee $100 \%$ protectionexposure [19]. So, other factors of respondents are not wearing PPE, smokers, and Frequent consumption of shellfish.

A research conducted by Qoriah et al., (2015) showed that smokers among metal casting workers had higher levels of $\mathrm{Pb}(56.2 \%)$ compared with nonsmokers [20]. Rustanti and Mahawati (2011) also 
showed a significant relationship between smoking habits and the levels of $\mathrm{Pb}$ in the blood, the higher the number of cigarettes smoked, the higher the levels of $\mathrm{Pb}$. Furthermore, the absorption levels of $\mathrm{Pb}$ in the respiratory mucosa are influenced by smoking habits. The $\mathrm{Pb}$ content in cigarettes contributes to the level of exposure in the blood through its smoke and the number of cigarettes impacts on the exposure level [21].

Smoking correlated with higher National Institutes of Health Stroke Scale (NIHSS) scores on admission for small-vessel occlusion. Conversely, it was associated with lower NIHSS scores on admission for cardioembolism.

Among the respondents consuming shellfish, about $38.7,27.4$, and $6.5 \%$ had levels of $\mathrm{Hb}, \mathrm{Ht}$, and erythrocytes counts, respectively, lower than normal.

Lead $\mathrm{Pb}$ Exposure to $\mathrm{Pb}$ can occur from many sources but usually arises from industrial use that is around Tambak Lorok Waters like Tanjung Mas Harbor. It can occur from fishing vessels which are accidentally shedding their vessels fuel into the waters, too. Based on the result of the analysis, the accumulation of $\mathrm{Pb}$ in the body of Macridiscus sp. is not exceeding the MWI value yet. MTI values mussels which contaminated by $\mathrm{Pb}$ are high. It means the mussels are still safe for $\mathrm{Pb}$ consumption [22].

The $\mathrm{Pb}$ content in the soft tissue of the virgin shellfish (Anadara granosa L) in the Tanjung Emas Semarang waters is quite high [23].

The port in this region is very close to Tambaklorok where this study was conducted and its activities including that of other industries in the region could potentially increase the $\mathrm{Pb}$ in the city. These include paper factories common with wastes such as $\mathrm{Hg}, \mathrm{Pb}, \mathrm{Cd}$, and $\mathrm{Cr}$; ceramic factories with $\mathrm{Cd}$, $\mathrm{Pb}, \mathrm{Zn}$ wastes; workshops with $\mathrm{Cd}, \mathrm{Pb}, \mathrm{Zn}$, and $\mathrm{HCl}$ wastes; car body factories with $\mathrm{Pb}$ wastes; ship repair workshops with $\mathrm{Pb}$, and $\mathrm{Cu}$ wastes, as well as textile factories with $\mathrm{Pb}$ and $\mathrm{Cu}$ wastes. There are also many domestic waste disposal sites around the Tambaklorok area, common with used battery slabs and other $\mathrm{Pb}$-containing materials. Furthermore, paints used in painting ships within the area contain compounds such as $\mathrm{PbCO} 3$ and $\mathrm{Pb} 3 \mathrm{O} 4$, which could enter the estuary and cause high levels of $\mathrm{Pb}$.

This study has provided us that Macridiscus $\mathrm{sp}$. that taken from Tambaklorok water is not safe to be consumed by people at that time. It has contaminated by heavy metals such as $\mathrm{Pb}, \mathrm{Al}, \mathrm{Fe}, \mathrm{Cu}$, and $\mathrm{Mn}$. It can impact to body health if we consume it in excess. Besides that, This study may also provide an evaluation of relevant government policy related to waste and fishing village management environmentally [24].

For $38.6 \%$ of residents with over 30 years of stay, $42.2 \%$ with profession, $45.3 \%$ not wearing PPE, $26.7 \%$ smokers, and $38.7 \%$ of respondents of Tambaklorok had anemia. Furthermore, about $41 \%$ of these respondents had anemia with a significant relationship established between the use of PPE and the levels of of both $\mathrm{Hb}$ and $\mathrm{Ht}$ in their blood.

\section{Conclusion}

The conclusion is generally, $41 \%$ of Tambaklorok residents in Semarang had mild anemia based on the industrial activities in the region.

\section{Acknowledgments}

This study was support to the Institute for Research and Community Service, Universitas Muhammadiyah Semarang. The research was funded by Universitas Muhammadiyah Semarang.

\section{References}

1. Hoffbrand AV. Kapita Selekta Hematologi. 2013. p. 20-45.

2. McLean E. Worldwide prevalence of anaemia, WHO vitamin and mineral nutrition information system, 1993-2005. Public Health Nutr. 2009;12(4):444-54. https://doi.org/10.1017/ s1368980008002401

PMid:18498676

3. World Health Organization. World Health Assembly Global Nutrition Targets 2025: Anaemia Policy Brief. Geneva: World Health Organization Publication; 2014.

4. Indonesian Ministry of Health Research and Development Agency. Basic Health Research, Indonesia: Indonesian Ministry of Health Research and Development Agency; 2013. https://doi. org/10.17501/24246735.2018.4105

5. Chaparro CM, Suchdev PS. Anemia epidemiology, pathophysiology, and etiology in low- and middle-income countries. Ann N Y Acad Sci 2019;1450(1):15-31. https://doi. org/10.1111/nyas. 14092

PMid:31008520

6. Republic of Indonesia. Data and Information Center of the Ministry of Health of the Republic of Indonesia Smoking Behavior of Indonesian Society Public. Indonesia: Infodatin; 2014.

7. Keputusan Menteri Kesehatan. Basic Health Research Agency for Health Research and Development. Keputusan Menteri Kesehatan; 2009.

8. Arifin MS, Fadilah NA. Relationship between nutritional status and menstruation pattern with anemia incidence in adolescents. Indonesian: Indonesian Public Health Periodic; 2018.

9. Liu C. Association between blood erythrocyte lead concentrations and hemoglobin levels in preschool children. Environ Sci Pollut Res 2015;22(12):9233-40. https://doi. org/10.1007/s11356-014-3992-3

PMid:25588596 
10. Santoso B. Zinc supplementation improves heme biosynthesis in rats exposed to lead. Univ Med. 2016;32(1):3-9.

11. UNEP. Study on the Possible Effects on Human Health and the Environment in Asia and the Pacific of the Trade of Products Containing Lead. Cadmium and Mercury. Nairobi, Kenya: UNEP.

12. Schwartz J, Landrigan PJ, Baker EL Jr., Orenstein WA, von Lindern IH. Lead induced anemia: Dose response relation and evidence for a threshold. Am J Public Health 1990;80(2):165-8. https://doi.org/10.2105/ajph.80.2.165 PMid:2297059

13. Drossos CG, Mavroidis KT, Papadopoulou-Daifotis Z, Michalodimitrakis DN, Salamalikis LX, Gounaris AK, et al. Environmental lead pollution in Greece. Am Ind Hyg Assoc J. 1982;43(10):796-8. https://doi. org/10.1080/15298668291410594 PMid:7148684

14. Froom P, Kristal-Boneh E, Benbassat J, Ashkanazi R, Ribak J. Lead exposure in battery-factors workers is not associated with anemia. J Occup Environ Med. 1999;41(2):120-3. https://doi. org/10.1097/00043764-199902000-00007 PMid:10029957

15. Kariada N. Air quality levels on protocol roads. Sainteknol 2011;29(8s):1675-81.

16. Lemeshow $\mathrm{S}$. Adequacy of sample size determination in health studies. In: Determination in Health Studies. Hoboken, New Jersey: John Wiley; 1990.

17. Rustanti I, Mahawati E. Factors related to blood levels of lead $(\mathrm{Pb})$ in public transport fish farmers department of Tambaklorok
Semarang city. J Public Health. 2011;10(1).

18. Soeripto M. Industrial Hygiene. 208:475.

19. Pratiwi TS. Factors Related to the Content of Blood $\mathrm{Pb}$ in Employees in the Vehicle Testing Section, the Department of Transportation. Yogyakarta: Doctoral dissertation, Diponegoro University; 2008.

20. Qoriah D, Setiani O, Dewanti N. Relationship between service levels and blood levels of lead $(\mathrm{Pb})$ in metal casting industry workers Cv. Bonjor Jaya in Batur Village, Ceper, Klaten. J Public Health 2015.

21. Lazarević K. Determination of lead and arsenic in tobacco and cigarettes: An important issue of public health. Cent Eur J Public Health 2012;20(1):62-6. https://doi.org/10.21101/cejph.a3728

PMid:22571020

22. World Health Organization. WHO Food Standards Programme Codex Committee on Contaminants in Foods. Geneva: World Health Organization; 2011.

23. Lee KR, Ko KD, Hwang IC, Suh HS, Kim KK. Association between blood lead levels and blood pressures in a non-smoking healthy Korean population. Postgrad Med J. 2017;93(1103):513-8. https://doi.org/10.1136/postgradmedj-2016-134208 PMid:27555608

24. Tielman EM, Suprijanto J, Widowati I. Safely intake number of Macridiscus sp. (Kerang Ceplos) from Tambak Lorok Waters, Semarang, Central Java, Indonesia. Yogyakarta, Indonesia: IOP Conference Series: Earth and Environmental Science, Volume $116,3^{\text {rd }}$ International Conference on Tropical and Coastal Region Eco Development 2017 2-4 October 2017; 2017. https:// doi.org/10.1088/1755-1315/116/1/012079 